\title{
First isolation and genetic characterization of a Toxoplasma gondii strain from a symptomatic human case of congenital toxoplasmosis in Romania
}

\author{
Carmen Anca Costache ${ }^{1}$, Horaţiu Alexandru Colosi ${ }^{2},{ }^{*}$, Ligia Blaga $^{3}$, Adriana Györke $^{4}$,
} Anamaria Ioana Paştiu ${ }^{4}$, Ioana Alina Colosi ${ }^{1}$, and Daniel Ajzenberg ${ }^{5,6}$

1 Department of Microbiology, "Iuliu Haţieganu" University of Medicine and Pharmacy, 6 Louis Pasteur street, Cluj-Napoca 400349, Romania

2 Department of Medical Informatics and Biostatistics, "Iuliu Haţieganu" University of Medicine and Pharmacy, 6 Louis Pasteur street, Cluj-Napoca 400349, Romania

3 Department of Neonatology, "Iuliu Haţieganu” University of Medicine and Pharmacy, 57 Bulevardul 21 Decembrie 1989, Cluj-Napoca 400124, Romania

${ }^{4}$ Department of Parasitology and Parasitic Diseases, Faculty of Veterinary Medicine, University of Agricultural Sciences and Veterinary Medicine, 3-5 Mănăştur street, Cluj-Napoca 400372, Romania

5 Centre National de Référence (CNR) Toxoplasmose/Toxoplasma Biological Resource Center (BRC), Centre Hospitalier-Universitaire Dupuytren, Limoges 87042, France

6 INSERM UMR 1094, Neuroépidémiologie Tropicale, Laboratoire de Parasitologie-Mycologie, Faculté de Médecine, Université de Limoges, Limoges 87025, France

Received 21 February 2013, Accepted 19 March 2013, Published online 29 March 2013

\begin{abstract}
Very limited data exists on the genetic diversity of Toxoplasma gondii from Eastern Europe. We present the first Romanian case of symptomatic congenital toxoplasmosis in which the T. gondii strain was isolated after inoculation in mice of a cerebrospinal fluid sample from a living neonate. The $T$. gondii strain was genotyped with 15 microsatellite markers distributed on 10 of the 14 chromosomes of $T$. gondii. The strain had a type II genotype.
\end{abstract}

Key words: Congenital toxoplasmosis, Genotyping, Eastern Europe.

\begin{abstract}
Résumé - Premier isolement avec caractérisation génétique d'une souche de Toxoplasma gondii en Roumanie, à partir d'un cas humain symptomatique de toxoplasmose congénitale. Il existe très peu de données sur la diversité génétique de Toxoplasma gondii en Europe de l'Est. Nous présentons le premier cas humain de toxoplasmose congénitale en Roumanie dans lequel la souche de $T$. gondii a été isolée chez la souris après inoculation d'un échantillon de liquide céphalo-rachidien d'un nouveau-né vivant. La souche de $T$. gondii a été génotypée avec 15 marqueurs microsatellites localisés sur 10 des 14 chromosomes de T. gondii. La souche avait un génotype de type II.
\end{abstract}

\section{Introduction}

Toxoplasma gondii (T. gondii) is a highly successful parasite, virtually capable of infecting all species of warm-blooded animals worldwide. Understanding genetic variation of $T$. gondii is critical in reducing the selection possibility of more virulent strains that could produce more severe or even new forms of toxoplasmosis [12].

\footnotetext{
*Corresponding author: hcolosi@umfcluj.ro
}

Isolation and genetic characterization of viable $T$. gondii strains have been described mostly in domestic animals from various geographical areas [6, 7, 10, 17, 20, 22]. The isolation and genetic characterization of clinical isolates of $T$. gondii have been predominantly performed in patients with congenital toxoplasmosis or with severe immunodeficiency conditions, as illustrated by several studies conducted in France [2, 4].

The population structure of this cosmopolitan parasite is complex, with distinct geographic patterns [15]. The highest genetic diversity of $T$. gondii has been described in South 
America, because a combination of a large gene pool and frequent genetic exchanges has generated a wide variety of different genotypes in this area $[14,18,21]$. In contrast to this high genetic variability, in Western Europe, the population structure of $T$. gondii is markedly clonal, with a huge predominance $(>90 \%)$ of strains belonging to the type II lineage, both in humans and animals $[1,13]$. The type III lineage is far less successful than the type II lineage in Western Europe, but can be observed in some cases [13]. Type I strains and the atypical ones that do not fit into the three major lineages are exceptionally collected in Western Europe [5,8].

In Eastern Europe, little is known about the genetic diversity of Toxoplasma gondii. In this geographic region, nonclonal strains of $T$. gondii have so far been isolated only from animal hosts and they have been exceptionally rare: two isolates from Polish chickens, which interestingly have been found to be identical to a nonclonal sheep isolate from Uruguay in South America [11]. To our knowledge, only 10 strains have been isolated and genotyped so far from human hosts living in Eastern Europe. These strains were collected from cases of human congenital toxoplasmosis, nine in Poland [19] and one in Serbia [9]. All of them were identified as type II genotypes. The genotyping of the nine cases of congenital toxoplasmosis from Poland was based on DNA amplified directly from amniotic fluid or from the cerebrospinal fluid of the infants [19]. Viable T. gondii was isolated from cord blood of the foetus in Serbia [9]. In both of these studies [9, 19], genotyping was based on restricted fragment length polymorphism, using five markers (5'SAG2, 3'SAG2, BTUB, SAG3, GRAO).

The present study is the first genetic characterization of a T. gondii strain isolated in Romania and the first characterization of a $T$. gondii strain from Eastern Europe using 15 microsatellite markers.

\section{Case report}

The case we present is that of a premature (32 weeks of gestational age) female neonate, born in July 2011, in Cluj-Napoca, Romania. The child was born spontaneously, in cranial presentation, with an Apgar score of 9/9. Due to IUGR (Intrauterine Growth Restriction), the newborn had decreased subcutaneous tissue, a fat index of 1.8 , a skull perimeter of $31 \mathrm{~cm}$ and a body weight of $2,000 \mathrm{~g}$. The anterior fontanelle exhibited interior tension and measured $2 / 2 \mathrm{~cm}$. Microphthalmia, axial hypotonia, and average respiratory distress were also present at birth. A congenital hydrocephalus had been diagnosed at 26 weeks of gestation. Serological investigation of the mother diagnosed an acute toxoplasmosis in the sixth month of pregnancy ( $\mathrm{IgG}$ and IgM switched from negative in the second month of pregnancy to positive in the sixth month of pregnancy) followed by treatment with spiramycin (Rovamycin ${ }^{\circledR}$ ) during the last month of pregnancy. Transfontanellar ultrasonography performed at $4 \mathrm{~h}$ after birth showed a dilated lateral ventricle compressing the brain mass, with a biventricular diameter at the level of Monroe's hole of $33.8 \mathrm{~mm}$. A magnetic resonance imaging (MRI) showed a complex brain malformation with agenesis of the corpus callosum, right frontal schizencephaly, and obstructive hydrocephalus. Examination of the eye revealed

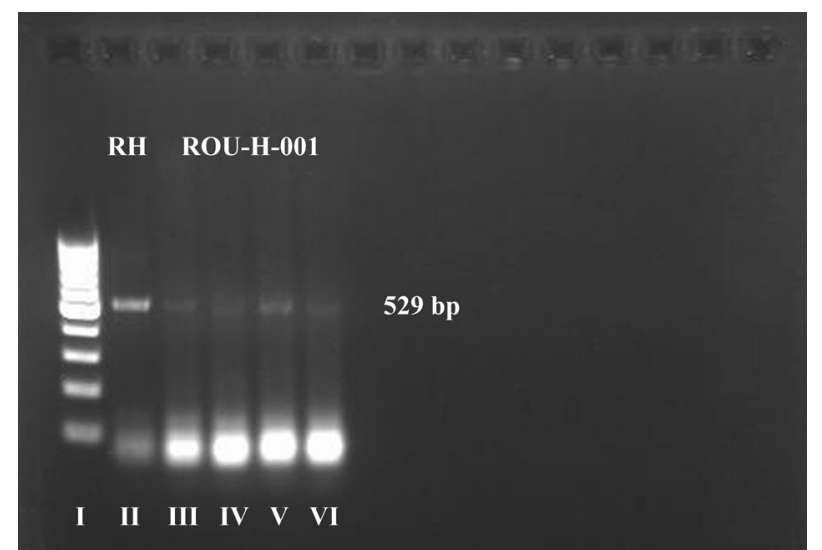

Figure 1. PCR products amplified with specific primer pairs for molecular identification of T. gondii, from child's CSF, migration into agarose gel 1.5\%. Lane I - $1 \mathrm{~kb}$ DNA ladder; lane II - positive control (RH strain); lanes III-VI - DNA amplified with $T$. gondii specific primers - PCR positive (ROU-H-001 strain).

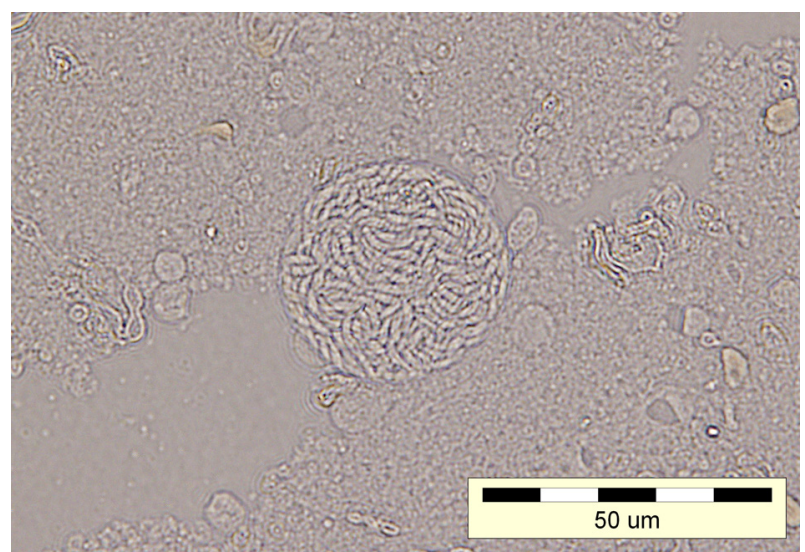

Figure 2. T. gondii cyst developing in the brain of an inoculated mouse; microscopic image of a preparation from the occipital lobes, photographed between a cover slide and a glass slide, 4 weeks after inoculation.

congenital acute central chorioretinitis of the right eye and sequelae of anterior and posterior uveitis, retinal detachment, and congenital microphthalmia of the left eye.

\section{Investigation results}

Specific serology against $T$. gondii with an enzyme immunoassay performed at 3 days after birth was positive for IgG (titer $>1000 \mathrm{IU} / \mathrm{mL}$, positive if $>50 \mathrm{IU} / \mathrm{mL}$; DiaPro, Italy) and for $\mathrm{IgA}$ (titer $=3.26 \mathrm{IU} / \mathrm{mL}$, positive if $>1 \mathrm{IU} / \mathrm{mL}$; BioRad, France), and equivocal for $\operatorname{IgM}$ (index $=0.95$, positive if $>1$, equivocal 0.8-1, negative $<0.8$; BioRad, France). A Western blot (LD-Bio) assay of the serum performed 3 weeks after birth was positive for IgG and IgM.

The cerebrospinal fluid (CSF) was collected 4 days after birth, analyzed by PCR (Figure 1), and bioassayed by mouse inoculation. After DNA extraction of the CSF sample (Qiagen, 
Table 1. Genotyping results of $T$. gondii DNA with 15 microsatellite markers from 5 reference strains collected in America and France, compared to the human strain collected in Romania.

Microsatellite markers

\begin{tabular}{lllllllllllllllllll} 
Type & \multicolumn{1}{c}{ Isolate $^{1}$} & Origin & Host & TUB2 & W35 & TgM-A & B18 & B17 & M33 & IV.1 & XI.1 & M48 & M102 & N60 & N82 & AA & N61 & N83 \\
\hline I & CT1 & USA & Cow & 291 & 248 & 209 & 160 & 342 & 169 & 274 & 358 & 209 & 168 & 145 & 119 & 265 & 87 & 306 \\
II & TgH32006 & France & Human & 289 & 242 & 207 & 158 & 336 & 169 & 274 & 356 & 215 & 174 & 142 & 111 & 281 & 91 & 310 \\
II & TgA32132 & France & Sheep & 289 & 242 & 207 & 158 & 336 & 169 & 274 & 356 & 221 & 174 & 138 & 111 & 277 & 91 & 312 \\
III & NED & France & Human & 289 & 242 & 205 & 160 & 336 & 165 & 278 & 356 & 209 & 190 & 147 & 111 & 267 & 91 & 312 \\
Atypical & TgCatBr5 & Brazil & Cat & 291 & 242 & 205 & 160 & 362 & 165 & 278 & 356 & 237 & 174 & 140 & 111 & 265 & 89 & 314 \\
II & ROU-H-001 & Romania & Human & 289 & 242 & 207 & 158 & 336 & 169 & 274 & 356 & 231 & 176 & 138 & 109 & 273 & 93 & 312 \\
\hline
\end{tabular}

${ }^{1}$ TgA32132 is also known as FR-OVI-ARI061 strain. All reference strains are available at the Toxoplasma Biological Resource Center (http://www.toxocrb.com).

Germany), a PCR-based assay with primers Tox 4 and Tox 5 detected the 200- to 300-fold repetitive 529 bp DNA fragment of T. gondii. Thus, the diagnosis of congenital toxoplasmosis was confirmed and treatment was initiated with spiramycin (Rovamycin $^{\circledR}$, Aventis, France) - $80 \mathrm{mg} / \mathrm{kg} /$ day, for 5 weeks after birth, followed by Pyrimethamine (Daraprim ${ }^{\circledR}$, GlaxoSmithKline) - $6 \mathrm{mg} /$ day, in association with folic acid $1 \mathrm{mg} /$ day and monitoring of hematological parameters.

The CSF sample was bioassayed into three Swiss white mice. The CSF was centrifuged and resuspended in a saline solution containing penicillin $\mathrm{G}$ and streptomycin. This homogenate was inoculated i.p. (0.5 mL/mouse) into three mice. Four weeks post-inoculation all three mice were still asymptomatic, however, the microscopic examination of their brain tissue revealed the presence of $T$. gondii cysts (Figure 2).

The $T$. gondii strain was designated as ROU-H-001 and banked at the Toxoplasma Biological Resource Center under the Accession Number TgH113001. It was submitted to DNA extraction (Qiagen, Germany) for a genotyping analysis using 15 microsatellite markers distributed on 10 of 14 chromosomes of $T$. gondii, as described elsewhere [3]. Briefly, for each primer pair, the forward one was $5^{\prime}$-end labeled with fluorescein to allow sizing of PCR products electrophoresed in an automatic sequencer. PCR was carried out in a $25-\mu \mathrm{L}$ reaction mixture consisting of $12.5 \mu \mathrm{L}$ of 2X QIAGEN Multiplex PCR Master Mix (Qiagen, France), 5 pmol of each primer, and $5 \mu \mathrm{L}$ of DNA. Cycling conditions were $15 \mathrm{~min}$ at $95^{\circ} \mathrm{C} ; 30 \mathrm{~s}$ at $94{ }^{\circ} \mathrm{C}, 3 \mathrm{~min}$ at $61{ }^{\circ} \mathrm{C}, 30 \mathrm{~s}$ at $72{ }^{\circ} \mathrm{C}(35$ cycles $)$, and $30 \mathrm{~min}$ at $60{ }^{\circ} \mathrm{C}$. PCR products were diluted $1: 10$ with deionized formamide. One microliter of each diluted PCR product was mixed with $0.5 \mu \mathrm{L}$ of a dye-labeled size standard (ROX 500, Applied Biosystems) and $23.5 \mu \mathrm{L}$ of deionized formamide (Applied Biosystems). This mixture was denatured at $95{ }^{\circ} \mathrm{C}$ for $5 \mathrm{~min}$ and then electrophoresed using an automatic sequencer (ABI PRISM 3130xl, Applied Biosystems). The sizes of the alleles in bp were estimated using GeneMapper analysis software (version 4.0, Applied Biosystems).

The analyzed $T$. gondii strain had a type II genotype (Table 1).

\section{Discussion}

A preliminary genetic comparison of this human $T$. gondii strain with three animal strains collected from the same area of Romania revealed that even though the animal strains were also of type II, they were not identical, exhibiting minor genetic differences at the most polymorphic microsatellite markers. A complete genetic analysis of these animal strains will be published in the near future. Neither the human strain described in this paper nor the three animal strains isolated from the same area of Romania were found to be identical to other type II strains collected in France and genotyped with the same 15 microsatellite markers so far.

\section{Conclusions}

Although genetic data available for $T$. gondii strains from Romania is currently very limited, it would appear that the genetic diversity of T. gondii in Eastern Europe may be close to that observed in Western Europe, with a predominance of type II strains in animals and humans, even though minor genetic variations have been detected with microsatellite markers. The question that could be addressed is whether atypical genotypes divergent from the clonal lineage II are more prevalent in Eastern Europe than in Western Europe. This issue is of paramount importance because there is a growing body of data suggesting that atypical strains are more pathogenic in congenital toxoplasmosis than type II strains $[8,16]$. There is a need of extending our knowledge regarding the genetic variability distribution of this highly successful parasite. Our results pave the way for conducting further studies in order to isolate and characterize more human and animal $T$. gondii strains from Eastern Europe, as well as other underinvestigated regions of Europe.

Acknowledgements. This work was funded by a research grant of the "Iuliu Haţieganu" University of Medicine and Pharmacy, ClujNapoca, Romania (Grant No. 27020/41/15.11.2011).

\section{References}

1. Ajzenberg D, Bañuls AL, Tibayrenc M, Dardé ML. 2002. Microsatellite analysis of Toxoplasma gondii shows considerable polymorphism structured into two main clonal groups. International Journal for Parasitology, 32, 27-38.

2. Ajzenberg D, Cogné N, Paris L, Bessières MH, Thulliez P, Filisetti D, Pelloux H, Marty P, Dardé ML. 2002. Genotype of 86 Toxoplasma gondii isolates associated with human 
congenital toxoplasmosis, and correlation with clinical findings. Journal of Infectious Diseases, 186, 684-689.

3. Ajzenberg D, Collinet F, Mercier A, Vignoles P, Dardé ML. 2010. Genotyping of Toxoplasma gondii isolates with 15 microsatellite markers in a single multiplex PCR assay. Journal of Clinical Microbiology, 48, 4641-4645.

4. Ajzenberg D, Yera H, Marty P, Paris L, Dalle F, Menotti J, Aubert D, Franck J, Bessières MH, Quinio D, Pelloux H, Delhaes L, Desbois N, Thulliez P, Robert-Gangneux F, Kauffmann-Lacroix C, Pujol S, Rabodonirina M, Bougnoux ME, Cuisenier B, Duhamel C, Duong TH, Filisetti D, Flori P, Gay-Andrieu F, Pratlong F, Nevez G, Totet A, Carme B, Bonnabau H, Dardé ML, Villena I. 2009. Genotype of 88 Toxoplasma gondii isolates associated with toxoplasmosis in immunocompromised patients and correlation with clinical findings. Journal of Infectious Diseases, 199, 1155-1167.

5. Ajzenberg D. 2010. Type I strains in human toxoplasmosis: myth or reality? Future Microbiology, 5, 841-843.

6. Al-Kappany YM, Rajendran C, Abu-Elwafa SA, Hilali M, Su C, Dubey JP. 2010. Genetic diversity of Toxoplasma gondii isolates in Egyptian feral cats reveals new genotypes. Journal of Parasitology, 96, 1112-1114.

7. Al-Qassab S, Reichel MP, Su C, Jenkins D, Hall C, Windsor PA, Dubey JP, Ellis J. 2009. Isolation of Toxoplasma gondii from the brain of a dog in Australia and its biological and molecular characterization. Veterinary Parasitology, 164, 335-339.

8. Delhaes L, Ajzenberg D, Sicot B, Bourgeot P, Dardé ML, Dei-Cas E, Houfflin-Debarge V. 2010. Severe congenital toxoplasmosis due to a Toxoplasma gondii strain with an atypical genotype: case report and review. Prenatal Diagnosis, 30, 902-905.

9. Djurković-Djaković O, Klun I, Khan A, Nikolić A, KnezevićUsaj S, Bobić B, Sibley LD. 2006. A human origin type II strain of Toxoplasma gondii causing severe encephalitis in mice. Microbes and Infection/Institut Pasteur, 8, 2206-2212.

10. Dubey JP, Hill DE, Rozeboom DW, Rajendran C, Choudhary S, Ferreira LR, Kwok OC, Su C. 2012. High prevalence and genotypes of Toxoplasma gondii isolated from organic pigs in Northern USA. Veterinary Parasitology, 188, 14-18.

11. Dubey JP, Huong LT, Lawson BW, Subekti DT, Tassi P, Cabaj W, Sundar N, Velmurugan GV, Kwok OC, Su C. 2008. Seroprevalence and isolation of Toxoplasma gondii from freerange chickens in Ghana, Indonesia, Italy, Poland, and Vietnam. Journal of Parasitology, 94, 68-71.

12. Grigg ME, Suzuki Y. 2003. Sexual recombination and clonal evolution of virulence in Toxoplasma. Microbes and Infection/ Institut Pasteur, 5, 685-690.

13. Halos L, Thébault A, Aubert D, Thomas M, Perret C, Geers R, Alliot A, Escotte-Binet S, Ajzenberg D, Dardé ML, Durand B,
Boireau P, Villena I. 2010. An innovative survey underlining the significant level of contamination by Toxoplasma gondii of ovine meat consumed in France. International Journal for Parasitology, 40, 193-200.

14. Khan A, Miller N, Roos DS, Dubey JP, Ajzenberg D, Dardé ML, Ajioka JW, Rosenthal B, Sibley LD. 2011. A monomorphic haplotype of chromosome Ia is associated with widespread success in clonal and nonclonal populations of Toxoplasma gondii. mBio, 2, e00228-11.

15. Lehmann T, Marcet PL, Graham DH, Dahl ER, Dubey JP. 2006. Globalization and the population structure of Toxoplasma gondii. Proceedings of the National Academy of Sciences of the United States of America, 103, 11423-11428.

16. McLeod R, Boyer KM, Lee D, Mui E, Wroblewski K, Karrison T, Noble AG, Withers S, Swisher CN, Heydemann PT, Sautter M, Babiarz J, Rabiah P, Meier P, Grigg ME. 2012. Toxoplasmosis study group. Prematurity and severity are associated with Toxoplasma gondii alleles (NCCCTS, 1981-2009). Clinical Infectious Diseases, 54, 1595-1605.

17. Mercier A, Devillard S, Ngoubangoye B, Bonnabau H, Bañuls AL, Durand P, Salle B, Ajzenberg D, Dardé ML. 2010. Additional haplogroups of Toxoplasma gondii out of Africa: population structure and mouse-virulence of strains from Gabon. PLoS Neglected Tropical Diseases, 4, e876.

18. Minot S, Melo MB, Li F, Lu D, Niedelman W, Levine SS, Saeij JP. 2012. Admixture and recombination among Toxoplasma gondii lineages explain global genome diversity. Proceedings of the National Academy of Sciences of the United States of America, 109, 13458-13463.

19. Nowakowska D, Colón I, Remington JS, Grigg M, Golab E, Wilczynski J, Sibley LD. 2006. Genotyping of Toxoplasma gondii by multiplex PCR and peptide-based serological testing of samples from infants in Poland diagnosed with congenital toxoplasmosis. Journal of Clinical Microbiology, 44, 13821389.

20. Rajendran C, Su C, Dubey JP. 2012. Molecular genotyping of Toxoplasma gondii from Central and South America revealed high diversity within and between populations. Infection, Genetics and Evolution, 12, 359-368.

21. Su C, Khan A, Zhou P, Majumdar D, Ajzenberg D, Dardé ML, Zhu XQ, Ajioka JW, Rosenthal BM, Dubey JP, Sibley LD. 2012. Globally diverse Toxoplasma gondii isolates comprise six major clades originating from a small number of distinct ancestral lineages. Proceedings of the National Academy of Sciences of the United States of America, 109, 5844-5849.

22. Zhou P, Zhang H, Lin RQ, Zhang DL, Song HQ, Su C, Zhu XQ. 2009. Genetic characterization of Toxoplasma gondii isolates from China. Parasitology International, 58, 193-195.

Cite this article as: Costache CA, Colosi HA, Blaga L, Györke A, Pastiu AI, Colosi IA \& Ajzenberg D: First isolation and genetic characterization of a Toxoplasma gondii strain from a symptomatic human case of congenital toxoplasmosis in Romania. Parasite, 2013, 20, 11 . 
Reviews, articles and short notes may be submitted. Fields include, but are not limited to: general, medical and veterinary parasitology; morphology, including ultrastructure; parasite systematics, including entomology, acarology, helminthology and protistology, and molecular analyses; molecular biology and biochemistry; immunology of parasitic diseases; host-parasite relationships; ecology and life history of parasites; epidemiology; therapeutics; new diagnostic tools.

All papers in Parasite are published in English. Manuscripts should have a broad interest and must not have been published or submitted elsewhere. No limit is imposed on the length of manuscripts.

Parasite (open-access) continues Parasite (print and online editions, 1994-2012) and Annales de Parasitologie Humaine et Comparée (1923-1993) and is the official journal of the Société Française de Parasitologie. 